\title{
Mission Statements of Hospitals: An Empirical Analysis of Their Contents and Their Relationship to Organizational Factors
}

\author{
Ram Subramanian \\ Grand Valley State University \\ Allendale, Michigan \\ Kamalesh Kumar \\ Charles C. Yauger \\ Arkansas State University \\ State University, Arkansas
}

\section{Introduction}

The 1980s saw a dramatic shift in the external environment faced by health care organizations. Changes such as increased competition, demographic shifts [14], and increased cost-consciousness from "customers" in the form of the government and other employers who paid for their employees' health care costs have transformed this industry significantly [12]. The domain of health care organizations now became similar to the environment faced by organizations in the more traditional industries such as automobiles and manufacturing. Observers are of the opinion that the rules for success in the health care industry now include better management skills and the implementation of strategic planning programs ([14], [19]).

Strategic planning involves aligning the organization in terms of its environment [24]. An important step in the strategic planning process is the development of a statement that delineates the organization's mission. Such a statement, called the "mission" statement or the "credo", helps the organization define itself and differentiate it from its competitors [22]. Johnson and Johnson's successful handling of the Tylenol crisis has been attributed largely to the guidance provided by its mission statement [10]. The company's mission clearly states that its first responsibility is to the users of its products. Such an unequivocal prioritization of purpose enabled the company's managers to take whatever actions possible to get the defective product out of the market and design a new package that would prevent a similar crisis from happening again.

There has been an increasing amount of research done on mission statements in recent times. Much of the research, though, has used mixed samples drawn from manufacturing and service companies. In other words, very few studies have looked at mission statements from an industry specific viewpoint. As Pearce and David [22] point out, further research is needed to determine particular industries, conditions, and situations where specific components of a mission statement are useful.

The objectives of this paper are:

(1) to empirically analyze mission statements of hospitals,

(2) to examine the relationship between mission statement components and organizational characteristics such as size and profit orientation, as well as occupancy rate (a factor denoting performance), and 
(3) to examine the relationship between comprehensiveness (in terms of the inclusion of mission statement components) and the three factors indicated above.

The paper is divided into four parts. The first part reviews the literature on mission statements, while the second part describes the research methodology. The third part presents the results of the study and the implications are discussed in the fourth part.

\section{Review of the Literature}

\section{Mission Statements in the General Setting}

As Pearce and David [22] observe, while strategic management textbooks dwell at length on the importance of mission statements, research interest in this area has been scant until recently. While Table 1 summarizes the extant research on mission statements, three studies are described in detail here because they directly provide the theoretical backdrop for the current effort.

Table 1: Review of Mission Statement Literature

\begin{tabular}{|c|c|c|c|}
\hline Author(s) & Article Intent & Methodology & Findings \\
\hline $\begin{array}{l}\text { Campbell and } \\
\text { Yeung (1991) }\end{array}$ & Theory building & $\begin{array}{l}\text { Interviews } \\
\text { with } 42 \\
\text { companies. }\end{array}$ & $\begin{array}{l}\text { Commitment } \\
\text { to mission is } \\
\text { best when there } \\
\text { is a match } \\
\text { between employ- } \\
\text { ees' values and } \\
\text { company's val- } \\
\text { ues. }\end{array}$ \\
\hline $\begin{array}{l}\text { Klemm, et al } \\
\text { (1991) }\end{array}$ & Theory testing & $\begin{array}{l}\text { Survey and } \\
\text { content } \\
\text { analysis of } \\
59 \text { statements. }\end{array}$ & $\begin{array}{l}\text { Mission } \\
\text { statement } \\
\text { important tool } \\
\text { for managers. }\end{array}$ \\
\hline Ackoff (1987) & Prescription & Discussion. & $\begin{array}{l}\text { Participation in } \\
\text { mission statement } \\
\text { preparation is } \\
\text { important for its } \\
\text { success. }\end{array}$ \\
\hline
\end{tabular}


Spring 1993 Subramanian, Kumar \& Yauger: Mission Statements

Table 1: Review of Mission Statement Literature (Continued)

\begin{tabular}{|c|c|c|c|}
\hline Author(s) & Article Intent & Methodology & Findings \\
\hline $\begin{array}{l}\text { Pearce and } \\
\text { David (1987) }\end{array}$ & Theory building & $\begin{array}{l}\text { Content } \\
\text { analysis of } \\
61 \text { Fortune } \\
\underline{500} \text { state- } \\
\text { ments. }\end{array}$ & $\begin{array}{l}\text { Eight components } \\
\text { found in most mis- } \\
\text { sion statements. } \\
\text { Also, more com- } \\
\text { prehensive state- } \\
\text { ments character- } \\
\text { istic of high } \\
\text { performers. }\end{array}$ \\
\hline David (1989) & Theory testing & $\begin{array}{l}\text { Content } \\
\text { analysis of } \\
75 \text { mission } \\
\text { statements. }\end{array}$ & $\begin{array}{l}\text { Service and manu- } \\
\text { facturing compa- } \\
\text { nies differ in the } \\
\text { inclusion of cer- } \\
\text { tain components. }\end{array}$ \\
\hline Pearce (1982) & Prescription & Discussion. & $\begin{array}{l}\text { Mission statements } \\
\text { are valuable tools } \\
\text { for strategic man- } \\
\text { agement. }\end{array}$ \\
\hline Want (1986) & Prescription & Discussion. & $\begin{array}{l}\text { Mission sets a } \\
\text { course for the } \\
\text { organization's } \\
\text { future. }\end{array}$ \\
\hline $\begin{array}{l}\text { Bettinger } \\
(1985)\end{array}$ & Prescription & Discussion. & $\begin{array}{l}\text { Successful strate- } \\
\text { gic planning de- } \\
\text { pends on a clear, } \\
\text { concise mission } \\
\text { statement. }\end{array}$ \\
\hline Nash (1988) & Prescription & Discussion. & $\begin{array}{l}\text { Good mission } \\
\text { statements pro- } \\
\text { vide a benchmark } \\
\text { for success. }\end{array}$ \\
\hline $\begin{array}{l}\text { Byars and } \\
\text { Neil (1987) }\end{array}$ & Prescription & Discussion. & $\begin{array}{l}\text { Development of a } \\
\text { mission statement } \\
\text { is an important } \\
\text { part of the strate- } \\
\text { gic planning pro- } \\
\text { cess. }\end{array}$ \\
\hline
\end{tabular}


Table 1: Review of Mission Statement Literature (Continued)

\begin{tabular}{llll}
\hline Author(s) & Article Intent & Methodology & Findings \\
\hline McGinnis & Prescription & Discussion. & $\begin{array}{l}\text { Mission state- } \\
\text { ments are a fun- } \\
\text { damental part of } \\
\text { an organization's } \\
\end{array}$ \\
& & $\begin{array}{l}\text { an orategic planning } \\
\text { process. }\end{array}$
\end{tabular}

Cochran

and David

(1986)

McMillan

(1985)

Gibson, et.

al (1990)
Theory testing

Prescription

Theory testing

Content
analysis of
61 company
and 74
university
mission
statements.

The tone and readability of mission statement are important if they are to be effective. statements.

Discussion, Identified components of a hospital's mission statement.

Survey of Identified popul176 hospital ar components of administrators. hospital mission statements.

Pearce and David's [22] empirical work on the mission statements of Fortune 500 companies was the first in-depth examination of the components of mission statements and their relationship to firm performance. Using content analysis of 61 statements, they concluded that eight components were commonly found in mission statements. These components were: target customers and markets, principal products or services, geographic domain, core technologies, concern for survival, growth, and profitability, company philosophy, company self-concept, and desired public image. Table 2 provides a list of the eight components. 
Table 2: List of Mission Statement Components Derived from Literature

1. Specification of target customers and market.

2. The identification of principal products or services.

3. The specification of geographic domain.

4. The identification of core technologies.

5. The expression of commitment to survival, growth, and profitability.

6. The specification of key elements in the company philosophy.

7. The identification of the company self-concept.

8. The identification of the company's desired public image.

Source: Pearce II, J. A., and David, F.R. "Corporate Mission Statements: The Bottom Line." Academy of Management Executive, 1(2), (1987) p. 109.

The researchers found the mission statements of better performing companies to be more comprehensive (in terms of the number of components included) than those of poor performers.

David [8] found the mission statements of service companies to be less comprehensive than those of manufacturing companies. Few service companies had mission statements that described the organization's philosophy and the core technology used. However, he did not find support for any link between comprehensiveness of mission statements and economic performance.

\section{Mission Statements in the Hospital Setting}

Gibson, Newton, and Cochran [13] studied mission statements of hospitals with a view to identifying their existence and usage. Using 176 survey responses from members of the "Society for Hospital Planning and Marketing of the American Hospital Association", they concluded that hospitals use mission statements much the same way as their counterparts in the business community. However, the researchers also noted strong disagreement by their respondents about the usefulness of mission statements for planning purposes. The disagreement also extended to the relevance of certain mission statement components. For example, more than 40 percent of the respondents felt that the self-concept component was irrelevant, while 28 percent felt the same way about the technology component. A detailed examination of the mission statements also revealed that unlike manufacturing companies, most hospital mission statements did not include the organizational goals, technology, and the public image components.

It is clear from the review of the literature that only exploratory work has been done in the realm of mission statements. With the exception of two studies ([8], [22]), little effort has been made by prior researchers to study mission statements comprehensively in an effort to link them and their components to salient organizational factors as well as performance. Such a linkage done in an industry-specific context will provide a better perspective on the usefulness of such statements. The current study attempts to fill the gap in the literature by replicating and extending prior research on mission statements. 


\section{Methodology}

Data for this study were collected as part of a larger study on the management practices in health care organizations. A six-part questionnaire was designed to collect data. The parts relevant to this study were those dealing with the existence of a formal, written mission statement, the inclusion of the eight literature-derived [22] mission statement components, and data concerning organizational characteristics such as number of beds and profit orientation. Data was also collected on performance of hospitals as reflected by the surrogate measure of occupancy rate. The presence of the eight components has been validated by the empirical work of David [8] and used in research on hospital mission statements by Gibson, Newton, and Cochran [13]. While it may be desirable to measure the productivity and efficiency of hospitals in terms of financial information, such data is difficult to obtain. The competitive situation facing many hospitals, the absence of a clear profit motive among some hospitals, and a lack of knowledge on the part of many administrators about what data to gather and how to use them makes them reluctant to respond to questionnaire surveys on the subject of organizational productivity and profits [7]. Nevertheless, the "American Hospital Association Guide to the Health Care Field" does contain data on a variety of factors, such as number of beds, total expenditures, number of admissions per year, and census (average number of in-patients) that may be reflective of performance. This study used occupancy rate as the performance measure since this data was easily obtainable and more reliable than other measures. Since this measure includes both hospital size (number of beds) and census (average number of in-patients receiving care each day), it allowed us to take into account two of the factors that have been frequently used to determine hospital differences [11].

A pilot study was conducted using a subset of the population used for the study itself. The pilot questionnaire was mailed to the executive officers of five hospitals. The participants were asked to complete the questionnaire and to comment about the length of time necessary to fill out the questionnaire, any survey questions or statements that needed clarification, methods of response improvement, and follow-up techniques. Personal interviews were also conducted with four of the five executive officers. Modifications were made to the questionnaire based on these suggestions. Also, alpha coefficients were computed for all items on the questionnaire. The eight mission statement components had a coefficient of alpha of 0.7789 , indicating the instrument's reliability.

From the "American Hospital Association Guide to the Health Care Field," 647 acute care hospitals from Southeastern United States (comprising the states of Arkansas, Missouri, Louisiana, Tennessee, Kentucky, Mississippi, Alabama, Georgia and South Carolina) were identified as the target group. This geographic area was selected for the convenience of the researchers in gathering data from a population large enough to yield an adequate number of responses. This strategy was quite successful in maximizing the number of responses. In terms of the generality of the findings of this study, we feel that the characteristics represented in this sample is also represen- 
tative of the characteristics of hospitals in other geographic regions. Feldstein [11] cited a number of variables frequently used to determine hospital differences. The list includes such factors as: hospital size, percentage occupancy of hospital beds, total expenditures, and payroll expenditures. Analyses of the sample population used in this study, in terms of these characteristics, show that the sample used in this study covers a wide range of hospitals and, therefore, can be deemed to represent the larger population on a nationwide level.

The questionnaires were sent to the chief administrators of the sample group. The initial mailing followed by a reminder resulted in 357 responses ( 55 percent) of which 339 were usable. A chi-square test indicated that the respondent group was consistent with the total population on the variables of occupancy rate $\alpha^{2}=15.37, p=$ $0.47)$ and size $\left(\chi^{2}=12.61, \mathrm{p}=0.36\right)$.

\section{Results}

\section{Presence of Literature-Derived Components}

Of the 339 responding organizations, 291 ( 85.8 percent) had a formal, written mission statement. This percentage is consistent with the findings of Gibson, Newton, and Cochran [13] in their work on hospital mission statements, but considerably higher than the percentage of Fortune 500 companies that have formal, written mission statements ([22], [8], [6]).

Table 3 lists the percentage of respondents' mission statements that included the eight literature-derived components.

\section{Table 3: Percentage of Mission Statements that Included Various Components}

\begin{tabular}{lc}
\hline Component & Percent Included \\
\hline & \\
Philosophy & 88 \\
Self concept & 48 \\
Desired public image & 86 \\
Target customers & 66 \\
Principal services & 59 \\
Geographic domain & 61 \\
Core technologies & 25 \\
Concern for survival, growth, & \\
and profitability & 84 \\
\hline
\end{tabular}

A vast majority ( 88 percent) of the sample mission statements included the basic beliefs component, while the desired public image and concern about survival, growth, 
and profitability components were included in a large number (86 and 84 percent, respectively) of the sample mission statements. The least popular components were the identification of the technology used to deliver the hospital's services (25 percent) and a description of the hospital's strengths (48 percent).

Relationship of Components to Organizational Characteristics and Performance

A comparison of the inclusion of the eight components of the sample mission statements in relation to profit-orientation and organizational size are shown in Tables 4 and 5.

Table 4: Relationship Between Mission Statements and Occupancy

\begin{tabular}{|c|c|c|c|c|c|c|c|c|}
\hline \multirow[t]{2}{*}{ Component } & \multicolumn{2}{|c|}{$\begin{array}{l}\mathbf{L o w}^{\mathrm{a}} \\
(\mathrm{n}=79)\end{array}$} & \multicolumn{2}{|c|}{$\begin{array}{l}\text { Moderate } \\
(n=142)\end{array}$} & \multicolumn{2}{|c|}{$\begin{array}{l}\text { High } \\
(\mathrm{n}=70)\end{array}$} & \multirow[t]{2}{*}{$x^{2}$} & \multirow[t]{2}{*}{$\mathbf{P}^{\mathrm{b}}$} \\
\hline & Yes & $\mathrm{No}^{\mathrm{c}}$ & Yes & No & Yes & No & & \\
\hline $\begin{array}{l}\text { Philosophy } \\
\text { Image } \\
\text { Self Concept } \\
\text { Target Cust. }\end{array}$ & $\begin{array}{l}85 \\
64 \\
21 \\
59\end{array}$ & $\begin{array}{l}15 \\
36 \\
79 \\
41\end{array}$ & $\begin{array}{l}88 \\
88 \\
45 \\
61\end{array}$ & $\begin{array}{l}12 \\
12 \\
55 \\
39\end{array}$ & $\begin{array}{l}89 \\
89 \\
62 \\
68\end{array}$ & $\begin{array}{l}11 \\
11 \\
38 \\
32\end{array}$ & $\begin{array}{l}1.77 \\
10.18 \\
10.22 \\
1.17\end{array}$ & $\begin{array}{l}<.30 \\
<.06 \\
<.001 \\
>.50\end{array}$ \\
\hline $\begin{array}{l}\text { Services } \\
\text { Geo. Domain } \\
\text { Technology } \\
\text { Concerns }\end{array}$ & $\begin{array}{l}43 \\
56 \\
22 \\
68\end{array}$ & $\begin{array}{l}57 \\
44 \\
78 \\
32\end{array}$ & $\begin{array}{l}60 \\
59 \\
24 \\
81\end{array}$ & $\begin{array}{l}40 \\
41 \\
76 \\
19\end{array}$ & $\begin{array}{l}71 \\
63 \\
27 \\
82\end{array}$ & $\begin{array}{l}29 \\
37 \\
73 \\
18\end{array}$ & $\begin{array}{l}10.57 \\
0.49 \\
0.32 \\
2.18\end{array}$ & $\begin{array}{l}<.01^{*} \\
>.80 \\
>.80 \\
>.30\end{array}$ \\
\hline
\end{tabular}

a Low $=$ occupancy of $49 \%$ or less, moderate $=50-69 \%$, high $=>70 \%$

b Degrees of freedom $=2$

c Percent Response

* significant at the 0.05 level 
Table 5 compares the presence of the eight components in relation to occupancy rates.

Table 5: Relationship Between Mission Statements and Size

\begin{tabular}{|c|c|c|c|c|c|c|c|c|}
\hline \multirow[t]{2}{*}{ Component } & \multicolumn{2}{|c|}{$\begin{array}{l}\text { Smalla } \\
(n=85)\end{array}$} & \multicolumn{2}{|c|}{$\underset{(n=114)}{\text { Medium }}$} & \multicolumn{2}{|c|}{$\begin{array}{l}\text { Large } \\
(n=92)\end{array}$} & \multirow[t]{2}{*}{$x^{2}$} & \multirow[t]{2}{*}{$\mathbf{P b}$} \\
\hline & Yes & $\mathrm{No}^{\mathrm{c}}$ & Yes & No & Yes & No & & \\
\hline Philosophy & 90 & 10 & 94 & 6 & 97 & 3 & 4.90 & $<.10$ \\
\hline Image & 87 & 13 & 86 & 14 & 82 & 18 & 0.67 & $>.70$ \\
\hline Self Concept & 47 & 53 & 44 & 56 & 51 & 49 & 1.01 & $>.60$ \\
\hline Target Cust. & 62 & 38 & 67 & 33 & 66 & 34 & 0.38 & $>.80$ \\
\hline Services & 61 & 39 & 59 & 41 & 56 & 44 & 0.48 & $>.80 *$ \\
\hline Geo. Domain & 56 & 44 & 62 & 38 & 70 & 30 & 6.15 & $<.05^{*}$ \\
\hline Technology & 19 & 81 & 27 & 73 & 28 & 72 & 2.01 & $>.30$ \\
\hline Concerns & 83 & 17 & 80 & 20 & 85 & 15 & 0.87 & $>.60$ \\
\hline
\end{tabular}

a Small $=200$ or less beds, medium $=$ between 201 and 399 beds, large $=400$ or more beds.

$b$ Degrees of freedom $=2$

c Percent response

significant at the 0.05 level

Table 6: Relationship Between Mission Statements and Profit Orientation of Hospitals

\begin{tabular}{lcccccccc}
\hline Component & $\begin{array}{c}\text { Government }^{\mathrm{a}} \\
(\mathrm{n}=\mathbf{1 4 8})\end{array}$ & $\begin{array}{c}\text { Not-for-profit } \\
(\mathrm{n}=\mathbf{8 0})\end{array}$ & \multicolumn{2}{c}{$\begin{array}{c}\text { For-profit } \\
(\mathbf{n}=63)\end{array}$} & $\chi^{\mathbf{2}}$ & P $^{\mathrm{b}}$ \\
& Yes & No $^{\mathrm{c}}$ & Yes & No & Yes & No & & \\
& & & & & & & & \\
Philosophy & 80 & 20 & 84 & 16 & 99 & 1 & 4.05 & $>.10$ \\
Image & 85 & 15 & 83 & 17 & 3 & 7 & 2.71 & $>.20$ \\
Self Concept & 47 & 53 & 46 & 54 & 52 & 48 & 0.69 & $>.60$ \\
Target Cust. & 56 & 44 & 62 & 38 & 74 & 26 & 6.15 & $<.05^{*}$ \\
Services & 54 & 46 & 65 & 35 & 69 & 31 & 6.05 & $<.05^{*}$ \\
Geo. Domain & 43 & 57 & 60 & 40 & 71 & 29 & 10.49 & $<.001^{*}$ \\
Technology & 22 & 78 & 23 & 77 & 37 & 63 & 4.86 & $<.10$ \\
Concerns & 82 & 18 & 81 & 19 & 91 & 9 & 2.76 & $>.20$ \\
\hline
\end{tabular}

${ }^{a}$ Government $=$ State and County hospitals, not-for-profit $=$ Church and other non-profit organizations, for-profit = privately owned

$b$ Degrees of freedom $=2$

c Percent response

significant at the 0.05 level 
Consistent with health care industry practices [13], the sample organizations were divided into three groups based on occupancy and three groups based on size (number of beds). Thus, hospitals with occupancies of 49 percent or less were classified as "low", while those with occupancies of 50 to 69 percent were classified as "moderate". Hospitals were classified as "high" if their occupancies were 70 percent or more. Similarly, the organization's size was "small" if it had 200 or less beds, "medium" if it had between 201 and 399 beds, and "large" if it had 400 or more beds. Also, based on questionnaire responses, the sample was divided into government (federal, state, or county funded), not-for-profit, and for-profit hospitals. The objective of this classification was to examine the relationship between organizational size, performance, and profit orientation with inclusion of mission statement components.

The responses were converted to percentages and a chi-square analysis was used to examine the difference across the three groups for the three measures used (occupancy, size, and profit orientation). Based on occupancy, two components showed significant differences across the three groups-identification of strengths (self-concept) and principal services.

Division of the responding hospitals in terms of size (number of beds) indicated that only one component, location of principal services (geographic domain), showed significant difference in means across the three groups. The mean scores on the other seven components were not statistically significant.

Based on profit orientation, significant differences were found in the means of the three groups for three components: location of principal services (geographic domain), identification of customer groups (target customers and markets) and principal services. In all three cases, the incidence of these components was significantly greater in forprofit hospitals than in government and not-for-profit hospitals.

To test the relationship between comprehensiveness (in terms of inclusion of the eight components) and the three factors studied (size, profit orientation, and occupancy), the following procedure was used. First, a score of 1 was given if the mission statement did not include the particular component, while a score of 2 signified inclusion of the component. Based on these scores, a composite was obtained for each hospital by adding up the scores for the eight components. The composite score indicated the degree by which a hospital contained more or fewer of the eight components relative to others. An ANOVA (analysis of variance) was used to examine the difference between groups of hospitals divided on the basis of the three factors. Significant differences in comprehensiveness were observed only in profit-orientation (see Table 7). 
Table 7: Analysis of Variance of Comprehensiveness of Mission Statement and Hospital Size, Profit Orientation and Occupancy Rate

\begin{tabular}{llll}
\hline $\begin{array}{l}\text { Hospital } \\
\text { Characteristics }\end{array}$ & $\begin{array}{l}\text { Comprehensiveness } \\
\text { of Mission Statement }\end{array}$ & F-Statistics & P-value \\
\hline
\end{tabular}

Size

$\begin{array}{llll}\text { Small } & 10.92 & & \\ \text { Medium } & 10.99 & 0.87 & 0.42 \\ \text { Large } & 11.36 & & \end{array}$

Profit Orientation

$\begin{array}{llll}\text { Government } & 10.10 & & \\ \text { Not-for-profit } & 10.70 & 4.32 & 0.01^{*} \\ \text { For-profit } & 11.80 & & \end{array}$

Occupancy Rate

\begin{tabular}{llll} 
Low & 10.35 & & \\
Moderate & 10.55 & 1.04 & 0.24 \\
High & 11.11 & & \\
\hline
\end{tabular}

a Comprehensiveness measure has been calculated by adding up the responses to the eight components of the mission statement. It shows to what degree a hospital contains more or fewer of the eight components relative to others.

* Significant at the 0.05 level

\section{Discussion}

The importance of the health care sector is underscored by the fact that it currently accounts for about 12 percent of the country's GNP [3]. As competition in the industry increases, more and more health care organizations are applying management techniques that, hitherto were confined to the more traditional industries. However, as Fottler [12] points out, the environment of the health care industry is so unique that many of the generic management techniques cannot be applied directly. This leads to the need for examining the applicability of current management theory to health care organizations with a view to determining their generalizability [3].

Research interest in organizational mission statements has increased during recent times. However, much of the work has been using pooled samples drawn from a number of industries. To the best of the current researchers' knowledge, only one study [13] examined the mission statements of hospitals. The objective of this effort, therefore, was to replicate the work of Gibson, Newton, and Cochran [13] using a larger sample and extend it by examining the relationship between mission statements and organizational factors such as size and profit orientation as well as a performance measure, viz., occupancy rate. Using theory generated in a context-free (generic management) domain, its application to a context-specific (health care management) environment is examined [3]. 
The current study (as well as the Gibson, Newton, and Cochran [13] study on hospital mission statements) found more hospitals having mission statements (85.6 percent) than did Fortune 500 companies ([22], [8]). Two reasons could be attributed to this phenomenon. It is possible that the turbulent environment faced by hospitals, especially in the $1980 \mathrm{~s}$, has forced administrators to clearly articulate their vision of the organization and its place in the competitive environment [9]. In this environment, successful hospitals (and those that survive) are those that spend more time communicating and coordinating goals among organizational subunits, and more thought and effort determining what society will appreciate [15]. Often, the mission statement is the starting point for such an objective.

The second reason for a large incidence of mission statements in hospitals may also be due to the fact that many hospitals, because of religious and/or charitable affiliations, have extensive prior experience in developing written statements about issues such as purpose and goals, which are also mission statement components [13]. Lack of experience in similar endeavors was cited as the primary reason by many Fortune 500 companies for not having mission statements [22].

Pearce and David's [22] study of mission statements of Fortune 500 companies indicated that two components-concern about survival, growth, and profitability, and desired public image-were found in a majority of statements. However, in the case of hospital mission statements, the current study identified the basic beliefs component to be the most popular. A large number of the responding hospitals ( 88 percent) included this component in their mission statements. This could again, be attributed to the fact that many hospitals either are, or have been, affiliated with religious and/or charitable institutions, where a written articulation of purpose is often necessary to get started. Components such as strengths (48 percent), identification of principal services ( 59 percent), and geographic domain (61 percent) were less popular. However, only 25 percent ( 74 out of 291 statements) included the component identifying the core technology to be used in delivering the hospital's services. The reasons for this could possibly be drawn from Pearce and David's [22] study on Fortune 500 companies' mission statements. In that study, two reasons were attributed for only 20 percent of the companies including the core technologies component in their mission statement. The first was the difficulty in succinctly describing the several technologies used in producing many products. Presumably, those companies that produced many different kinds of products were unable to describe briefly the different technologies that went into the production of these products. A hospital can be envisaged as an entity delivering many kinds of services-akin to a company producing multiple products. It is possible that this leads to the difficulty in identifying succinctly the technologies that go into the various services that a hospital provides. The second reason that emerged from the Pearce and David [22] study was that service technologies are far more difficult to identify than manufacturing technologies. Since hospitals are in the service sector, the difficulty in identifying the technologies used presumably leads to only a few organizations including this component in their mission statements. 
Pearce and David [22] provided empirical support for their contention that better performing organizations differed from their poor performing counterparts in the inclusion of certain mission statement components. Their study indicated that high performers and low performers differed significantly in the inclusion of the beliefs (basic philosophy), image, and strengths (self concept) components. However, they also argue that the desirability of including certain components could vary across industries. The current study provided partial empirical support for that argument.

Hospitals that showed higher occupancy rates (high performers) were significantly different from moderate and low performers in the inclusion of the strengths (selfconcept) and identification of principal services components. Hospitals are thus similar to other organizations in the inclusion of the strengths component, yet different in including the identification of the principal services component.

Due to a lack of prior research effort in this direction, one can only speculate on the reasons for these two components being included more often in better performing hospitals than in the moderate and poor performers. A clear identification and articulation of the organization's strengths helps prioritize its activities [9] and position it in terms of its environment [14]. This prioritization is extended to activities such as allocation of resources as well as in the external communication of the organization's abilities. This, presumably, helps draw patients to the hospital, thereby increasing its occupancy.

A clear identification of the hospital's principal services is also important, both for strategic planning as well as for external communication purposes. Industry experts (e.g., [16]) point out that in the future successful hospitals will be those that communicate clearly the various benefits (services) the organization provides to its myriad stakeholders. Inclusion of this component in its mission statement helps in communicating this information to the users of its services, thereby yielding better occupancy rates.

The number of beds in a hospital indicates its relative size. Only one component, location of principal services (geographic domain), showed significant difference in means across the three groups of hospitals. As a hospital's size increases, it often becomes unnecessary to specify its domain of activities. This component appears to be more necessary for smaller hospitals which have to clearly state its geographic domain, lest they get caught up in competition they cannot effectively compete in.

For-profit hospitals in the sample differed significantly from government and notfor-profit hospitals in the inclusion of three mission statement components: principal services, target customers, and geographic domain (location of principal services). It is possible that these three components were found more in for-profit hospitals than in the others because of the profit orientation of these hospitals. These three components specifically help focus an organization's resources in ways that would help it create and sustain a competitive advantage [25]. On the other hand, since the focus of government and not-for-profit hospitals is usually on providing service (not necessarily on a profit-making basis), it is possible that these three components are not considered extremely important. 
In looking at comprehensiveness of mission statements, only the grouping of hospitals by their profit-orientation yield significant differences. It indicated that for-profit hospitals contain more mission statement components than government and not-for-profit hospitals. It is difficult to establish a direct link between comprehensiveness of mission statements and the performance of the organization. Performance may be determined by a variety of factors, some specific to the organization, others related to general industry trends. However, a more comprehensive mission statement is the starting point for strategic planning purposes. It helps to clearly articulate an organization's position on various domains. Such articulation helps prioritize its activities.

The findings of this study are important for strategic management scholars as well as for hospital administrators. By extending research generated in general manufacturing and service industries, using a sample drawn from the health care field, this study demonstrated the need to consider the industry context in theory building. While many of the current study's results were consistent with those of Pearce and David [22] and David [8], the differences that were found signify that the health care context is quite different from that of general manufacturing and services and underscore the necessity of doing research using industry specific samples.

For the hospital administrator, the findings of this study describe the state-of-the art practices in strategic planning in the industry. By grouping the sample hospitals according to size, profit orientation, and occupancy rates, the presence or absence of literature-derived mission statement components were clearly portrayed. By identifying significant differences in the inclusion of certain components among the different groups of hospitals, the study's results provide pointers to hospital administrators. In addition, the study also looked at the relationship between the comprehensiveness of mission statement components and the three factors studied. While, except in the case of profit orientation, the differences were not significant, the current study attempts to build theory in the field of health care strategic planning by extending empirical research drawn from the general strategic planning field.

\section{Limitations and Future Research Directions}

One of the limitations of the current study was that the data was based on survey responses. Thus, it examined "intended" actions, and not "actual" ones. Future research using content analysis of hospital mission statements may lend further empirical support to the findings of the current study. Such an analysis is necessary to complement the current effort.

Future research should also examine how mission statements are actually used in strategic planning. Currently, one can only speculate on the benefits of mission statements. An examination of their use in setting objectives, generating strategic alternatives, as well as in helping select alternatives will provide objective data instead of subjective speculations. 


\section{References}

1. Ackoff, R.L. “Mission Statements." Planning Review, Vol. 15 (1987), pp. 30-31.

2. Bettinger, C. "Behind the Mission Statement." ABA Banking Journal, Vol. 127 (1985), pp. 154-160.

3. Blair, J.D. and Boal, K.B. "Strategy Formation Processes In Health Care Organizations: A Context-specific Examination of Context-free Strategy Issues." Journal of Management, Vol. 17 (1991), pp. 305-344.

4. Byars, L.L. and Neil, T.C. "Organizational Philosophy and Mission Statements." Planning Review, Vol. 15 (1987), pp. 32-35.

5. Campbell, A. and Yeung, S. "Creating a Sense of Mission." Long Range Planning, Vol. 24 (1991), pp. 10-20.

6. Cochran, D.S. and David, F.R. "Communication Effectiveness of Organizational Mission Statements." Journal of Applied Communication Research, Vol. 14 (1986), pp. 108-118.

7. Coddington, D.C. and Moore, K.D. Market-driven Strategies In Health-care. San Francisco, Califomia: Jossey-Bass Publishers (1987).

8. David, F.R. "How Companies Define Their Mission." Long Range Planning, Vol. 22 (1989), pp. 90-97.

9. Denis, J., Langley, A., and Lozeau, D. "Formal Strategy In Public Hospitals." Long Range Planning, Vol. 24 (1991), pp. 71-81.

10. Falsey, T.A. Corporate Philosophies and Mission Statements. New York: Quorum Books (1989).

11. Feldstein, M. The Rising Cost of Health Care. Washington D.C: The Information Resource Press (1971).

12. Fottler, M.D. "Health Care Organizational Performance: Present and Future Research." Journal of Management, Vol. 13 (1987), pp. 367-391.

13. Gibson, C.K., Newton, D.J., and Cochran, D.S. "An Empirical Investigation of the Nature of Hospital Mission Statements." Health Care Management Review, Vol. 15 (1990), pp. 35-45.

14. Ginter, P.M., Duncan, W.J., Richardson, W.D., and Swayne, L.E. Analyzing the Health Care Environment: "You Can't Hit What You Can't See." Health Care Management Review, Vol. 16 (1991), pp. 35-48. 
15. Griffith, J.R. "The Mission of the Well-managed Community Hospital." Michigan Hospitals, Vol. 24 (1988), pp. $43-46$.

16. Johnson, D.E.L. "Multi-unit Providers Will Focus on Benefits Rather Than Size." Health Care Strategic Management, Vol. 9 (1991), pp. 2-3.

17. Klemm, M., Sanderson, S., and Luffman, G. "Mission Statements: Selling Corporate Values to Employees." Long Range Planning, Vol. 24 (1991), pp. 73-78.

18. McGinnis, V.J. "The Mission Statement: A Key Step in Strategic Planning." Business, November-December (1981), pp. 39-43.

19. McMillan, N.H. "The Mission Statement: Where It All Begins." In Planning for Survival: A Handbook for Hospital Trustees (1985). Chicago, Ilinois: American Hospital Association.

20. Nash, L. "Mission Statements-Mirrors and Windows." Harvard Business Review, MarchApril (1988), pp. 155-156.

21. Pearce, II, J.A. "The Company Mission as a Strategic Tool." Sloan Management Review, Spring (1982), pp. 15-25.

22. Pearce, II, J.A. and David, F.R. "Corporate Mission Statements: The Bottom Line." Academy of Management Executive, Vol. (2) (1987), pp. 109-116.

23. Want, J.H. "Corporate Mission: The Intangible Contributor to Performance." Management Review, August (1986), pp. 46-50.

24. Zahra, S.A. "Corporate Strategic Types, Environmental Perceptions, Managerial Philosophies and Goals: An Empirical Study." Akron Business and Economic Review, Vol. 18 (1987), pp. 64-77.

25. Zaleznik, A. "Power and Politics in Organizational Life." Harvard Business Review, 48(3) (1970), pp. $47-60$. 